\title{
Peritubular Contractile Cells in Testis and Epididymis of the Dog, Canis lupus familiaris
}

\author{
Gunter F. Egger, Kirsti Witter \\ Institute of Histology and Embryology, Department of Pathobiology, \\ University of Veterinary Medicine Vienna, Austria \\ Received August 20, 2008 \\ Accepted December 15, 2008
}

\begin{abstract}
Contractile cells surrounding the tubular system of the mammalian testis and epididymis are supposed to contribute to the initial transport of spermatozoa from the testis to epididymis. Testicular peritubular smooth muscle cells have been characterised in detail especially in rodents and humans. The aim of our study was to assess the distribution of peritubular contractile cells of the canine tubuli seminiferi, rete testis channels, ductuli efferentes, and ductus epididymidis by immunohistochemistry and transmission electron microscopy and to classify these cells with respect to their possible physiological function. The entire tubular system of the canine testis and epididymis is surrounded by contractile cells expressing smooth muscle actin, smooth muscle myosin and desmin, which are enveloped, at least partly, by a basal lamina. Some contractile cells of the tubuli seminiferi, rete channels, and efferent ducts and sometimes also single peritubular cells of the ductus epididymidis express vimentin. Contractile cells of seminiferous tubules and efferent ducts represent an intermediate cell type exhibiting characteristics of both smooth muscle cells (SMC) and myofibroblasts, those of rete channels stellate myofibroblasts, and those of the ductus epididymidis SMC. Differences in structure and arrangement of the contractile cells between seminiferous tubules, rete channels, efferent ducts, and ductus epididymidis suggest different functions. Myofibroblasts and contractile cells similar to them could be mainly responsible for the maintenance of an appropriate tissue turgor, whereas contraction of SMC of the ductus epididymidis might cause propulsion of spermatozoa by peristaltic waves.
\end{abstract}

Myofibroblasts, smooth muscle cells, sperm transport, immunohistochemistry, electron microscopy

Contractile cells in the peritubular tissue (lamina propria) of the mammalian testis are supposed to contribute to the initial transport of spermatozoa from the testis to the epididymis. In the lamina propria of the seminiferous tubules, contractile cells have been found in many mammalian species such as the rat, mouse, hamster, rabbit, cat, sheep, cattle, pig and human (Roosen-Runge 1951; Ross and Long 1966; Ross 1967; Böck et al. 1972; Bressler and Ross 1972; Bustos-Obregón and Holstein 1973; De Kretser et al. 1975; Hargrove et al. 1977; Wrobel et al. 1979; Maekawa et al. 1996). Similar cells surround the channels of the rete testis (Roosen-Runge and Holstein 1978; Hees et al. 1989).

The structure, quantity, and layering of testicular contractile cells vary by species (Maekawa et al. 1996). In early studies, the cells were usually referred to as myoid cells without further classification (Ross and Long 1966; Dierichs and Wrobel 1973; Bustos-Obregón and Courot 1974). Contractile cells surrounding the seminiferous tubules of rodents have recently been analysed in great detail and are usually termed peritubular smooth muscle cells (for overview, see e.g. Maekawa et al. 1996; Tripiciano et al. 1999; Romano et al. 2005, and references therein), although they seem to differ considerably from other smooth muscle cells (Romano et al. 2005). In some species, such as cattle and humans, these cells share characteristics with fibroblasts and have therefore been termed myofibroblasts (Böck et al. 1972; Wrobel et al. 1979; Hees et al. 1989; Holstein et al. 1996; Maekawa et al. 1996). In boars, only cells of the

Address for correspondence:

K. Witter

Institute of Histology and Embryology

Department of Pathobiology

University of Veterinary Medicine Vienna

Veterinärplatz 1, 1210 Wien, Austria

Phone: +43 1250773403

Fax: +43 1250773490

E-mail: kirsti.witter@vu-wien.ac.at

http://www.vfu.cz/acta-vet/actavet.htm 
inner peritubular layer are contractile, whereas outer layers consist of fibroblasts (Pinart et al. 2001).

Studies on contractile cells surrounding rete channels and efferent ducts of mammals are rather rare (Baumgarten et al. 1971; Viotto et al. 1993; Rodríguez et al. 1999; Devkota et al. 2006), although they can also be expected to play a considerable role in the sperm transport. Contractile cells of the lamina propria of the ductus epididymidis are generally characterised as smooth muscle cells (Baumgarten et al. 1971; Whittington et al. 2001; see also textbooks on human and veterinary histology).

Myofibroblasts resemble smooth muscle cells (SMC) in their contractility and their cytoskeletal proteins, but fibroblasts in their biosynthetic phenotype and their response to the regulation operated by extracellular matrix and mechanical forces (Lefebvre et al. 1994). They are usually spindle-shaped or stellate with long cytoplasmic extensions and characterised by a discontinuous basal lamina. Compared to SMC, myofibroblasts have a larger Golgi apparatus and abundant rough endoplasmic reticulum, both indicating their synthetic activity (Eyden 2005). The microfilaments are arranged in bundles (stress fibres). Microfilaments form 'dense bodies' where they accumulate and insert in plasmalemmal attachment plaques. The nucleus is mostly indented. Immunohistochemical studies have shown that myofibroblasts feature heterogeneous cytoskeletal phenotypes. Hence various types of myofibroblasts according to their content of specific cytoskeletal filaments such as alpha-smooth muscle actin, desmin, myosin and vimentin have been described (JostarndtFögen et al. 1998; Schürch et al. 1998).

In contrast, SMC are usually characterised as smooth spindle-shaped cells with numerous membrane caveolae, which are enveloped by a continuous basal lamina. Their cytoplasm contains uniformly distributed microfilament bundles that run in parallel to the long axis of the cells. The nucleus is elongated with blunt ends (Zhang et al. 1997; Schürch et al. 1998; Eyden et al. 1999). However, definition of differentiated SMC is difficult, since variations in marker gene expression depend upon the functional state of the individual cell, as described e.g. for contractile cells of the airways or for vascular SMC (JostarndtFögen et al. 1998; Tang 2008).

Precise data on the nature of contractile cells surrounding the tubular system of canine testis and epididymis are not available; the present study was performed to assess the distribution of these cells and to classify them with respect to their possible physiological function.

\section{Materials and Methods}

Samples and preparation of histological sections

Testicles including the epididymis of six young adult dogs (Canis lupus familiaris) were obtained after routine orchiectomy requested by the dog owners. The dogs did not suffer from any known impairment of spermatogenesis. Three tissue blocks of a volume of approximately $0.5 \times 2 \times 2 \mathrm{~cm}$ were taken from each of these 12 testicles, so that all parts of the tubular system within the organs could be examined. Tissue samples were fixed in buffered formalin according to Lillie, in Methacarn or in Bouin's solution (Romeis 1989), dehydrated and embedded in paraffin. Sections were cut at 3-5 $\mu \mathrm{m}$ thickness and routinely stained with Mayer's haematoxylin and eosin.

Immunohistochemistry - single staining

The presence of the cytoskeletal filaments smooth muscle actin, desmin, smooth muscle myosin and vimentin was studied immunohistochemically in order to detect and to classify contractile tissue elements. One section per tissue block and antibody (i.e., 36 sections per antibody) was mounted on poly-L-lysine coated slides, deparaffinised and rehydrated. Endogenous peroxidase activity was blocked with $0.6 \% \mathrm{H}_{2} \mathrm{O}_{2}$ in methanol, nonspecific binding activity with normal goat serum (DakoCytomation, Glostrup, Denmark) in phosphate-buffered salt solution (PBS) at room temperature. Antigen retrieval by digestion with $0.5 \mathrm{mg}$ protease from Streptomyces griseus (Sigma, Vienna, Austria)/ml PBS for $15 \mathrm{~min}$ at room temperature was required for detection of desmin, microwave pre-treatment $(2 \times 5 \mathrm{~min}$ in $0.01 \mathrm{M}$ citrate buffer, $\mathrm{pH} 6.0)$ for the detection of vimentin and myosin. Sections were incubated overnight with primary antibodies (manufacturer and dilution, see Table 1 ) at $4{ }^{\circ} \mathrm{C}$. Products of the immunoreaction of anti-desmin, anti-myosin and anti-vimentin were detected using the anti-mouse PowerVision Kit (Immunovision Technologies, Daly City, CA, USA). Binding of anti-smooth muscle actin was 
Table 1. Primary antibodies used for immunohistochemistry

\begin{tabular}{|c|c|c|}
\hline Antibody & Manufacturer & Dilution \\
\hline Monoclonal Mouse Anti-Human & DakoCytomation, Glostrup, & $1: 400$ \\
Smooth Muscle Actin, Clone 1A4 & Denmark & $(1: 150-1: 200$ double staining $)$ \\
\hline Monoclonal Mouse Anti-Human & DakoCytomation, Glostrup, & $1: 300$ \\
Desmin, Clone D33 & Denmark & $(1: 150$ double staining $)$ \\
\hline $\begin{array}{c}\text { Monoclonal Mouse Anti-Human } \\
\text { Smooth Muscle Myosin, Clone } \\
\text { hSM-V }\end{array}$ & Sigma, St. Louis, MO, USA & $1: 300$ \\
\hline $\begin{array}{c}\text { Monoclonal Mouse Anti-Human } \\
\text { Vimentin, Clone V9 }\end{array}$ & DakoCytomation, Glostrup, & $1: 200$ \\
\hline
\end{tabular}

detected with an avidin-biotin-peroxidase-complex (Vectastain $\mathrm{ABC} \mathrm{Kit}^{\mathrm{TM}}$, Vector Laboratories, Burlingame, CA, USA) after incubation of the sections with a biotinylated anti-mouse IgG antibody (Vector Laboratories, Burlingame, CA, USA). The reactions were visualised with diaminobenzidine (Sigma-Aldrich, Vienna, Austria) in $0.03 \% \mathrm{H}_{2} \mathrm{O}_{2}$ in TRIS buffered saline ( $\mathrm{pH}$ 7.4). All sections were counterstained with Mayer's haematoxylin, dehydrated and mounted with a medium soluble in xylene. For negative control, normal goat serum was used instead of the primary antibody.

Immunohistochemistry - double staining

In order to characterise the intermediate filaments of peritubular contractile cells in the testis and epididymis, smooth muscle actin/desmin and smooth muscle actin/vimentin double staining was performed. The desmin/ vimentin double staining served for detection of cells with both fibroblastic (vimentin) and smooth muscle (desmin) intermediate filaments. Two sections per staining of four selected methacarn-fixed tissue blocks were prepared (i.e., eight sections per double staining). All sections were deparaffinised and rehydrated as described above. For antigen retrieval, the sections were microwaved for $5 \mathrm{~min}$ in Tris-EDTA (DakoCytomation, Glostrup, Denmark; pH 9.0), when necessary. Non-specific binding activity was blocked with normal goat serum (DakoCytomation, Glostrup, Denmark) in phosphate-buffered salt solution (PBS) at room temperature. Afterwards, the sections were incubated with the first antibody (manufacturer and dilution, see Table 1). The immunoreaction was detected with Alexa Fluor 488 goat anti-mouse or Alexa Fluor 568 goat anti-mouse antibodies (Molecular Probes-Invitrogen, Paisley, UK; 1:100). For the second immunostaining, the Vector M.O.M. immunodetection kit (Vector Laboratories, Burlingame, CA, USA) was used according to the instructions of the manufacturer, starting with the application of the blocking reagent. The second immunostaining was detected with Alexa Fluor 488 goat anti-mouse or Alexa Fluor 568 goat anti-mouse antibodies as described above, using the colour that was not used for the first staining.

Transmission electron microscopy

Testicles including the epididymis of two young adult dogs were sampled for transmission electron microscopy in such a way that all parts of the tubular system within the organs could be examined. Nine tissue blocks per testicle (i.e. 36 specimens) were fixed in $5 \%$ phosphate buffered $(\mathrm{pH}=7.4)$ glutaraldehyde and washed in Sörensen's phosphate buffer. The samples were post-fixed in 1\% osmium tetroxide in Sörensen's buffer. After a second wash in Sörensen's buffer they were dehydrated and routinely embedded in epoxy resin. Five ultra-thin sections per tissue block were double-stained with lead citrate and uranyl acetate and examined with an EM 900 electron microscope (Zeiss, Oberkochen, Germany).

\section{Results}

Contractile cells could be identified in the peritubular connective tissue (lamina propria) in all the examined segments of the male canine reproductive system (Plate I, Figs 1,2).

\section{Seminiferous tubules}

The lamina propria of the seminiferous tubules contained two to three layers of concentrically arranged spindle-shaped cells that stained intensely for actin, myosin and desmin (Fig. 1a-c). Only few cells, predominantly of the middle and outer cell layers contained vimentin (Fig. 1d). In contrast to the vimentin-positive contractile cells in the middle lamina propria layer, peripheral vimentin positive cells were devoid of the smooth muscle markers actin and desmin (Plate II, Fig. 2b-c).

Electron microscopy revealed bundles of collagen fibrils between the cell layers of 
the tubular lamina propria. The spindle shaped cells which stained positively for the contractile elements were enveloped almost completely by a basal lamina. Nevertheless, some gaps within the basal lamina could be observed. Each cell contained an elongated ovoid nucleus. Cytoplasmic microfilaments were uniformly distributed in the cells, they did not form bundles. Some fibrils coursed parallel to the long axis of the cells. Most fibrils ran, however, more or less transversally avoiding the nucleus and inserting in dense plasmalemmal granular material (attachment plaques). The cell surface was smooth nearly without caveolae. The elongated nucleus had blunt ends and a smooth surface (Plate III, Fig. 3).

\section{Rete testis}

The wide channels of the rete testis were lined with a simple cuboidal epithelium partly immunopositive for vimentin or desmin. Their lamina propria contained actin- and myosin-positive cells, which formed an incomplete single layer that was separated from the epithelium by a thick layer of collagen fibres. Single further actin- and myosin-positive cells were situated in the loose connective tissue between the rete channels (Fig. 1f-g). These cells reacted partly for desmin, partly for vimentin (Figs 1h-i, 2d-e). Cells containing both vimentin and desmin were rare (Fig. 2f).

The epithelium was supported by a thick basement membrane. Beneath the basement membrane, dense bundles of collagen fibres as described above and a few elastic fibres intermingled with the contractile cells forming an envelope around the rete tubules. The oblong stellate cells were provided with a discontinuous basal lamina and had several cytoplasmic extensions. Cytoplasmic filaments were not distributed uniformly within the cells. Bundles of filaments in the subplasmalemmal cytoplasm were situated parallel to the long axis of the cell and inserted in prominent plasmalemmal attachment plaques. The cell surface itself appeared smooth without any discernable caveolae. The elongated nucleus featured numerous minor indentations (Plate IV, Fig. 4).

\section{Efferent ducts}

Ductuli efferentes were lined by a single layer of columnar epithelium with regular basement membrane. The lamina propria consisted of one to two, sometimes even more, layers of spindle-shaped cells that contained actin, desmin, myosin and vimentin (Fig. 11-o). Analogical with the contractile cells of rete channels, actin positive cells contained either vimentin or desmin, whereas vimentin/desmin double positive cells were rare (Fig. 2g-i).

All these cells were enveloped by a discontinuous basal lamina. The microfilaments were not distributed uniformly but arranged in bundles (stress fibres) with dense bodies and inserted in plasmalemmal attachment plaques. Numerous caveolae invaginated from the cell surface. The elongated nucleus showed a smooth surface (Plate V, Fig. 5).

Ductus epididymidis

The epithelium of the ductus epididymidis rested on a basement membrane, surrounded by a lamina propria of four and more layers of circularly oriented spindle-shaped cells that showed positive immunoreaction for actin, desmin, myosin and occasionally also for vimentin (Fig. 1q-t). The number of cell layers increased toward the cauda epididymidis without considerable changes in cell morphology or intermediate filament expression. Nearly all contractile cells contained desmin but not vimentin. Vimentin/desmin double positive cells were virtually absent (Fig. 2k-m).

Electron microscopy revealed a continuous basal lamina enveloping these fusiform cells. Microfilaments were abundant, densely packed and distributed evenly within the cytoplasm, parallel to the long axis of the cell. They were associated with numerous dense bodies. Groups of numerous caveolae and interposed attachment plaques were seen at the cell surface (Plate VI, Fig. 6). 


\section{Discussion}

The entire tubular system of the canine testis and epididymis, including seminiferous tubules, rete channels, efferent ducts and ductus epididymidis, is surrounded by contractile cells, whose morphology and arrangement varies considerably dependent on the segment of the tubular system (Plate VII, Fig. 7). Exact classification of these contractile cells was not always possible, as myofibroblasts are still a controversial type of cells that are difficult to define and identify (Mentzel et al. 1998; Eyden 2001) and also SMC are a heterogeneous cell population depending on the organ, age and functional state (Tang 2008). Most of the testicular and epididymal peritubular contractile cells showed characteristics of myofibroblasts as well as of SMC regarding both immunohistochemical profile and ultrastructure. Strikingly, vimentin immunoreaction was often absent, even if the contractile cells had a distinct myofibroblast ultrastructure. Vimentin/desmin double positive cells could be found in the lamina propria of seminiferous tubules, rete channels, and efferent ducts, but they were rare. In the peritubular tissue layer of ductus epididymidis, they were nearly absent (Fig. 2).

Morphology of contractile cells in the lamina propria of seminiferous tubules suggests that they represent an intermediate between myofibroblasts and SMC. Ovoid nuclei without any discernible indentations, absence of stress fibres, and uniformly distributed microfilaments, which were arranged parallel to the long axis of the cells, are typical for SMC (Schürch et al. 1998). However, the discontinuity of the basal lamina indicates myofibroblasts. Positive immunoreactivity for actin, desmin and myosin does not help to classify these cells definitively, as both SMC and myofibroblasts can express these cytoskeletal proteins. Furthermore, all fibroblastic cells are generally thought to express vimentin (Osborn and Weber 1982). However, in the contractile cells surrounding the canine seminiferous tubules, vimentin positive cells were few and some of them, especially in the outer layer of the lamina propria, could not be classified as contractile cells for their lack of smooth-muscle actin. Similarly as in humans and other larger animals (for review, see Maekawa et al. 1996), the phenotype of canine peritubular contractile cells of the testis seem to show a gradient. The innermost cells adjacent to the basement membrane are more SMC-like, without vimentin but with desmin intermediate filaments, followed by a myofibroblastic cell layer containing even some cells that are staining for vimentin as well as for desmin and an outermost layer of fibroblastic cells. Interestingly, the ultrastructure of cells in the lamina propria cell layers did not differ considerably from each other.

The scattered contractile cells of the rete testis represented typical myofibroblasts (Sánchez et al. 1978; Schürch et al. 1992; Schürch et al. 1998; Powell et al. 1999) with discontinuous basal lamina, cytoplasmic processes, stress fibres inserting in prominent plasmalemmal attachment plaques, few subplasmalemmal caveolae, and nuclei with indentations. However, vimentin/desmin co-expression in these cells could be detected only rarely.

Contractile cells surrounding the efferent ducts showed crucial characteristics of myofibroblasts such as a discontinuous basal membrane, randomly oriented microfilaments, and often positive vimentin staining - either alone or in combination with desmin, but also smooth nuclei and many caveolae as typical for SMC. Just as the contractile cells of the seminiferous tubules they can therefore be classified as an intermediate cell type, but without the phenotype gradient as described above.

The cells building the contractile envelope around the ductus epididymidis were typical SMC with a continuous basal lamina and numerous caveolae. Although the number of cell layers was higher in the cauda epididymidis compared to the caput, the phenotype of contractile cells was constant.

Contractile cells in the mammalian testis supposedly participate in the expulsion of spermatozoa from the testis into the epididymis. Spermatozoa evince little motility while 
being retained within the testis, and begin to move vigorously only after passage into the epididymis (Hargrove et al. 1977; Trainer 1992). The mechanisms responsible for the initial transport of immotile sperm from the testis into the epididymis are still poorly understood (Middendorff et al. 2002). Several factors have been proposed to influence fluid flow and sperm transport. It was postulated that ciliary action within the efferent ducts moves sperm toward the ductus epididymidis. Recent calculations revealed insufficiency of ciliary action to significantly effect sperm transport (reviewed by Ilio and Hess 1994) but it is still agreed to have some auxiliary function (Wrobel 1998). Constant secretion of fluid by the seminiferous epithelium was found to play a role in the transport of sperm (Ilio and Hess 1994). Another motive source for impelling sperm from the seminiferous tubules through the rete testis into the epididymis, which has been described in various mammals and humans, is the activity of contractile cells of the testicular tunic (Gorgas and Böck 1974; Leeson and Cookson 1974; Leeson 1975; Middendorff et al. 2002), the lamina propria of the seminiferous tubules (Ross and Long 1966; Böck et al. 1972; Langford and Heller 1973; De Kretser et al. 1975; Ellis et al. 1981) or the rete testis (RoosenRunge and Holstein 1978). In experimental studies, it has been shown directly that these cells do considerably increase sperm transport from the testis (Ilio and Hess 1994).

Differences in structure and arrangement of peritubular contractile cells surrounding seminiferous tubules in comparison with rete channels, efferent ducts and ductus epididymidis, suggest, however, different functions of these cells. Myofibroblasts are known to develop from fibroblasts when loaded by tension (Grinnell and Ho 2002); tension also maintains the myofibroblastic phenotype (Hinz et al. 2001). Increasing substrate stiffness induces increasing force exertion by myofibroblasts (Wrobel et al. 2002). Thus, the main function of myofibroblasts is, additionally to matrix secretion, rather to exert constant force than to dislocate structures (Freyman et al. 2002; Pizzo et al. 2005). In contrast, the primary function of SMC is contraction and relaxation, i.e. shortening and elongation of structures - displacement (Hilgers and Webb 2005).

It can be speculated that myofibroblasts and contractile cells similar to them that surround seminiferous tubules, rete testis channels and efferent ducts, are mainly responsible for the maintenance of an appropriate tissue turgor whithin the testicles, whereas contraction of SMC of the ductus epididymidis might cause true peristaltic movement of this duct and therefore propulsion of spermatozoa. It would be interesting to test whether endothelin, vasopressin, or other substances that are known to induce contraction of peritubular SMC in vitro (for review, see e.g. Maekawa et al. 1996; Palombi et al. 2002; Romano et al. 2005) affect all the different contractile cells as found in the canine testis and epididymis in the same way. In vivo experiments in rats resulting in different changes of luminal pressure in seminiferous tubules compared to the ductus epididymidis (reviewed by Maekawa et al. 1996) showed that this might not be the case.

\section{Peritubulární kontraktilní buňky ve varleti a nadvarleti psa, Canis lupus familiaris}

Kontraktilní buňky, které obklopují systém kanálků varlete a nadvarlete savců, pravděpodobně přispívají $\mathrm{k}$ iniciálnímu transportu semenných buněk $\mathrm{z}$ varlete do nadvarlete. U hlodavců i u člověka byly již testikulární peritubulární hladké svalové buňky detailně popsány. Cílem naší studie bylo zhodnotit distribuci peritubulárních kontraktilních buněk obklopujících tubuli seminiferi, kanálky rete testis, ductuli efferentes a ductus epididymidis u psa za použití immunohistochemie a transmisní elektronové mikroskopie. Tyto buňky byly dále klasifikovány s ohledem na jejich eventuální fyziologickou funkci. Systém kanálků varlete a nadvarlete psa je v celém rozsahu obklopen kontraktilními buňkami, které exprimují $\alpha$-hladkosvalový aktin, hladkosvalový myosin i desmin. Tyto buňky jsou částečně či zcela obaleny vrstvou lamina basalis. Některé z kontraktilních 
buněk obklopujících tubuli seminiferi, kanálky rete testis a ductuli efferentes obsahují též vimentin, stejně jako i ojedinělé buňky ductus epididymidis. Kontraktilní buňky semenotvorných kanálků a ductuli efferentes představují intermediární typ buněk s vlastnostmi jak hladkých svalových buněk, tak i myofibroblastů. Kontraktilní buňky rete testis mají fenotyp hvězdicovitých myofibroblastů, zatímco kontraktilní buňky ductus epididymidis jsou hladké svalové buňky. Rozdíly ve struktuře a uspořádání kontraktilních buněk mezi semenotvornými kanálky, kanálky rete testis, ductuli efferentes a ductus epididymidis naznačují jejich odlišnou funkci. Myofibroblasty a buňky jim podobné by mohly být zodpovědné zejména za udržování vhodného turgoru tkání, zatímco kontrakce hladkých svalových buněk ductus epididymidis pravděpodobně působí propulsi semenných buněk peristaltickými vlnami.

\section{Acknowledgement}

We thank Prof. P. Böck for the many fruitful discussions on myofibroblasts, which helped us considerably to prepare this manuscript, and Ms. Ch. Bayer, Ms. S. Dolezal, Ms. M. Helmreich, Ms. W. Tschulenk and Ms. B. Wiehart for their excellent technical assistance.

\section{References}

Baumgarten HG, Holstein AF, Rosengren E 1971: Arrangement, ultrastructure, and adrenergic innervation of smooth musculature of the ductuli efferentes, ductus epididymidis and ductus deferens of man. Z Zellforsch Mikrosk Anat 120: 37-79

Böck P, Breitenecker G, Lunglmayr G 1972: Contractile fibroblasts (myofibroblasts) in the lamina propria of human seminiferous tubules. Z Zellforsch Mikrosk Anat 133: 519-527

Bressler RS, Ross MH 1972: Differentiation of peritubular myoid cells of the testis: effects of intratesticular implantation of newborn mouse testes into normal and hypophysectomized adults. Biol Reprod 6: 148-159

Bustos-Obregón E, Courot M 1974: Ultrastructure of the lamina propria in the ovine seminiferous tubule. Development and some endocrine considerations. Cell Tissue Res 150: 481-492

Bustos-Obregón E, Holstein AF 1973: On structural patterns of the lamina propria of human seminiferous tubules. Z Zellforsch Mikrosk Anat 141: 413-425

De Kretser DM, Kerr JB, Paulsen CA 1975: The peritubular tissue in the normal and pathological human testis. An ultrastructural study. Biol Reprod 12: 317-324

Devkota B, Sasaki M, Takahashi K, Matsuzaki S, Matsui M, Haneda S, Takahashi M, Osawa T, Miyake YI 2006 : Postnatal developmental changes in immunohistochemical localization of alpha-smooth muscle actin (SMA) and vimentin in bovine testes. J Reprod Dev 52: 43-49

Dierichs R, Wrobel KH 1973: Licht- und elektronenmikroskopische Untersuchungen an den peritubulären Zellen des Schweinehodens während der postnatalen Entwicklung. Anat Embryol 143: 49-64

Ellis LC, Groesbeck MD, Farr CH, Tesi RJ 1981: Contractility of seminiferous tubules as related to sperm transport in the male. Arch Androl 6: 283-294

Eyden B 2001: The myofibroblast: an assessment of controversial issues and a definition useful in diagnosis and research. Ultrastruct Pathol 25: 39-50

Eyden B 2005: The myofibroblast: a study of normal, reactive and neoplastic tissues, with an emphasis on ultrastructure. Part 1 - normal and reactive cells. J Submicrosc Cytol Pathol 37: 109-204

Eyden BP, Shanks JH, Ioachim E, Ali HH, Christensen L, Howat AJ 1999: Myofibroblastoma of breast: evidence favoring smooth-muscle rather than myofibroblastic differentiation. Ultrastruct Pathol 23: 249-257

Freyman TM, Yannas IV, Yokoo R, Gibson LJ 2002: Fibroblast contractile force is independent of the stiffness which resists the contraction. Exp Cell Res 272: 153-162

Gorgas K, Böck P 1974: Myofibroblasts in the rat testicular capsule. Cell Tissue Res 154: 533-541

Grinnell F, Ho CH 2002: Transforming growth factor beta stimulates fibroblast-collagen matrix contraction by different mechanisms in mechanically loaded and unloaded matrices. Exp Cell Res 273: 248-255

Hargrove JL MacIndoe MD, Ellis LC 1977: Testicular contractile cells and sperm transport. Fertil Steril 28: 1146-1157

Hees H, Wrobel KH, Kohler T, Abou Elmagd A, Hees I 1989: The mediastinum of the bovine testis. Cell Tissue Res 255: 29-39

Hilgers RH, Webb RC 2005: Molecular aspects of arterial smooth muscle contraction: focus on Rho. Exp Biol Med 230: 829-835

Hinz B, Mastrangelo D, Iselin CE, Chaponnier C, Gabbiani G 2001: Mechanical tension controls granulation tissue contractile activity and myofibroblast differentiation. Am J Pathol 159: 1009-1020

Holstein AF, Maekawa M, Nagano T, Davidoff MS 1996: Myofibroblasts in the lamina propria of human seminiferous tubules are dynamic structures of heterogeneous phenotype. Arch Histol Cytol 59: 109-125

Ilio KY, Hess RA 1994: Structure and function of the ductuli efferentes: a review. Microsc Res Tech 29: 432-467 
Jostarndt-Fögen K, Djonov V, Draeger A 1998: Expression of smooth muscle markers in the developing murine lung: Potential contractile properties and lineal descent. Histochem Cell Biol 110: 273-284

Langford GA, Heller CG 1973: Fine structure of muscle cells of the human testicular capsule: basis of testicular contractions. Science 179: 573-575

Leeson TS 1975: Smooth muscle cells in the rat testicular capsule: a developmental study. J Morphol 147: 171-185

Leeson TS, Cookson FB 1974: The mammalian testicular capsule and its muscle elements. J Morphol 144: 237-253

Lefebvre P, Nusgens BV, Lapiere CM 1994: Cultured myofibroblasts display a specific phenotype that differentiates them from fibroblasts and smooth muscle cells. Dermatology 189 (Suppl.): 65-67

Maekawa M, Kamimura K, Nagano T 1996: Peritubular myoid cells in the testis: their structure and function. Arch Histol Cytol 59: 1-13

Mentzel T, Dry S, Katenkamp D, Fletcher CD 1998: Low-grade myofibroblastic sarcoma: analysis of 18 cases in the spectrum of myofibroblastic tumors. Am J Surg Pathol 22: 1228-1238

Middendorff R, Müller D, Mewe M, Mukhopadhyay AK, Holstein AF, Davidoff MS 2002: The tunica albuginea of the human testis is characterized by complex contraction and relaxation activities regulated by cyclic GMP. J Clin Endocrinol Metab 87: 3486-3499

Osborn M, Weber K 1982: Intermediate filaments: Cell-type-specific markers in differentiation and pathology. Cell 31: 303-306

Palombi F, Filippini A, Chiarenza C 2002: Cell-cell interactions in the local control of seminiferous tubule contractility. Contraception 65: 289-291

Pinart E, Bonet S, Briz M, Pastor LM, Sancho S, García N, Badia E, Bassols J 2001: Morphological and histochemical characteristics of the lamina propria in scrotal and abdominal testes from postpubertal boars: correlation with the appearance of the seminiferous epithelium. J Anat 199: 435-448

Pizzo AM, Kokini K, Vaughn LC, Waisner BZ, Voytik-Harbin SL 2005: Extracellular matrix (ECM) microstructural composition regulates local cell-ECM biomechanics and fundamental fibroblast behavior: a multidimensional perspective. J Appl Physiol 98: 1909-1921

Powell DW, Mifflin RC, Valentich JD, Crowe SE, Saada JI, West AB 1999: Myofibroblasts. I. Paracrine cells important in health and disease. Am J Physiol-Cell Physiol 277: C1-C9

Rodríguez A, Rojas MA, Bustos-Obregón E, Urquieta B, Regadera J 1999: Distribution of keratins, vimentin, and actin in the testis of two South American camelids: vicuna (Vicugna vicugna) and llama (Lama glama). An immunohistochemical study. Anat Rec 254: 330-335

Romano F, Tripiciano A, Muciaccia B, De Cesaris P, Ziparo E, Palombi F, Filippini A 2005: The contractile phenotype of peritubular smooth muscle cells is locally controlled: possible implications in male fertility. Contraception 72: 294-297

Romeis B 1989: Mikroskopische Technik. 17th ed. by Böck P. Urban and Schwarzenberg, München-Wien, pp. 179-249

Roosen-Runge EC 1951: Motions of the seminiferous tubules of rat and dog. Anat Rec 153 (Suppl.): 109

Roosen-Runge EC, Holstein AF 1978: The human rete testis. Cell Tissue Res 189: 409-433

Ross MH 1967: The fine structure and development of the peritubular contractile cell component in the seminiferous tubules of the mouse. Am J Anat 121: 523-557

Ross MH, Long IR 1966: Contractile cells in human seminiferous tubules. Science 153: 1271-1273

Sánchez G, Díaz-Flores L, Hernández-Vallejo G, Gayoso MJ Caballero T 1978: Revisión conceptual del miofibroblasto (Conceptual review of myofibroblast). Morfol Norm Patol A-Histol 2: 119-132

Schürch W, Seemayer TA, Gabbiani G 1992: Myofibroblast. In: Sternberg SS (Ed.): Histology for pathologists. $2^{\text {nd }}$ ed. Raven Press, New York, pp. 109-144

Schürch W, Seemayer TA, Gabbiani G 1998: The myofibroblast: a quarter century after its discovery. Am J Surg Pathol 22: 141-147

Tang DD 2008: Intermediate filaments in smooth muscle. Am J Physiol-Cell Physiol 294: C869-C878

Trainer TD 1992: Testis and excretory duct system. In: Sternberg SS (Ed.): Histology for pathologists. $2^{\text {nd }}$ ed. Raven Press, New York, pp. 731-747

Tripiciano A, Peluso C, Morena AR, Palombi F, Stefanini M, Ziparo E, Yanagisawa M, Filippini A 1999: Cyclic expression of endothelin-converting enzyme-1 mediates the functional regulation of seminiferous tubule contraction. J Cell Biol 145: 1027-1038

Viotto MJ, Orsi AM, Vicentini CA, Camilli JA 1993: Ultrastructure of the boundary tissue of the extratesticular rete and efferent ductules in the cat (Felis domestica, L.)/Ultra-estrutura do tecido circundante da rede extratesticular e dos dúctulos eferentes no gato (Felis domestica, L.). Rev Bras Biol 53: 555-560

Wakui S, Furusato M, Ushigome S, Kano Y 1994: Coexpression of different cytokeratins, vimentin and desmin in the rete testis and epididymis in the dog. J Anat 184: 147-151

Whittington K, Assinder SJ, Parkinson T, Lapwood KR, Nicholson HD 2001: Function and localization of oxytocin receptors in the reproductive tissue of rams. Reproduction 122: 317-325

Wrobel KH 1998: Male reproductive system. In: Dellmann HD, Eurell J (Eds): Textbook of Veterinary Histology. Williams and Wilkins, Baltimore, pp. 226-246 
Wrobel KH, Mademann R, Sinowatz F 1979: The lamina propria of the bovine seminiferous tubule. Cell Tissue Res 202: 357-377

Wrobel LK, Fray TR, Molloy JE, Adams JJ Armitage MP, Sparrow JC 2002: Contractility of single human dermal myofibroblasts and fibroblasts. Cell Motil Cytoskeleton 52: 82-90

Zhang J, Hess MW, Thurnher M, Hobisch A, Radmayr C, Cronauer MV, Hittmair A, Culig Z, Bartsch G, Klocker H 1997: Human prostatic smooth muscle cells in culture: estradiol enhances expression of smooth muscle cellspecific markers. Prostate 30: 117-129 
Plate I

Egger G. et al.: Peritubular ... pp. 3-11

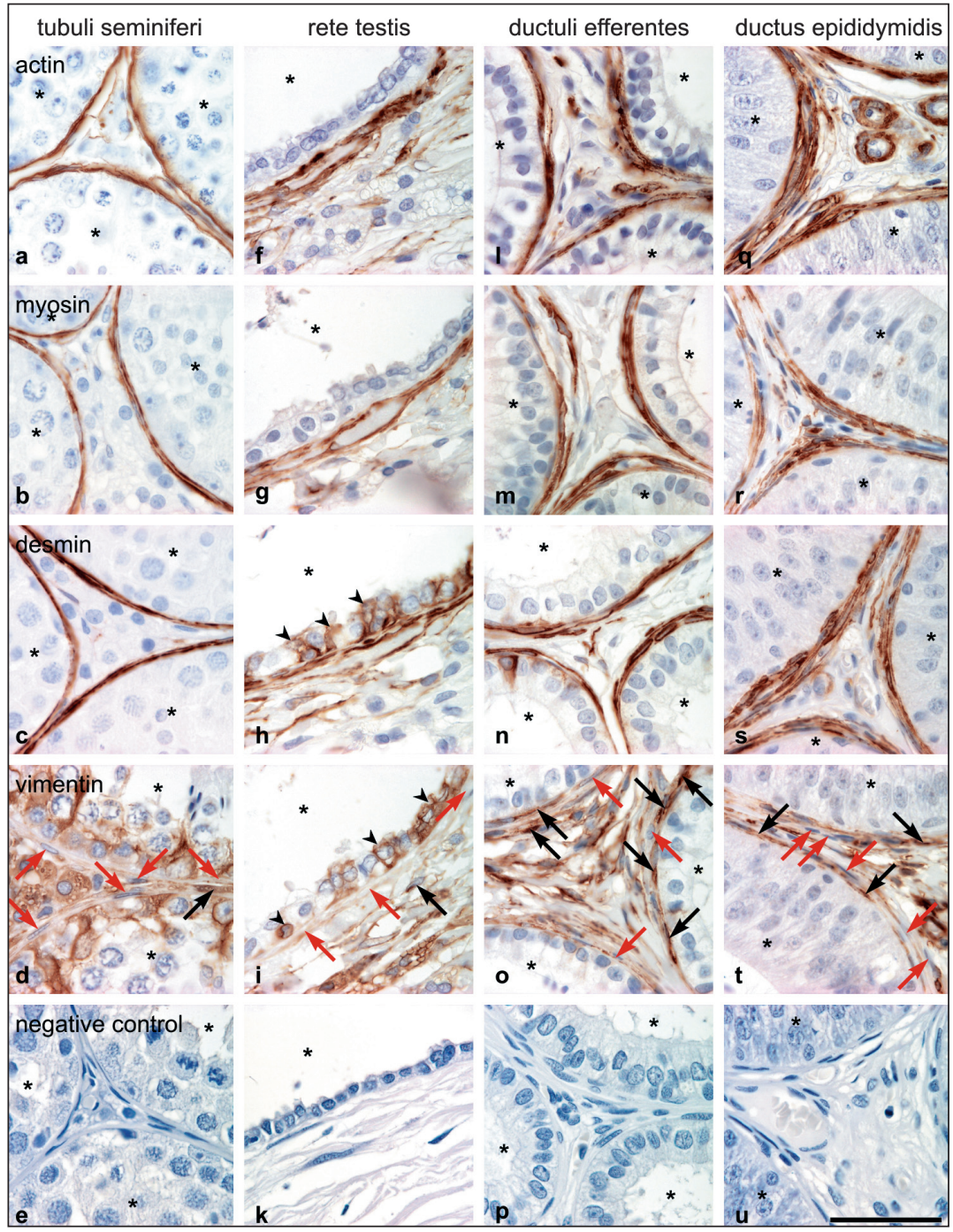

Fig. 1. Immunohistochemical characterisation of peritubular contractile cells in the canine testis and epididymis; tubuli seminiferi (a-e), rete testis channels (f-k), ductuli efferentes (l-p), and ductus epididymidis (q-u). Contractile cells surrounding all parts of the tubular system of both testis and epididymis stain positively (brown) for smooth muscle actin $(\mathbf{a}, \mathbf{f}, \mathbf{l}, \mathbf{q})$ and smooth muscle myosin $(\mathbf{b}, \mathbf{g}, \mathbf{m}, \mathbf{r})$. Desmin positivity is less pronounced in the peritubular cells of rete channels (h) in comparison with the other parts of the tubular system $(\mathbf{c}, \mathbf{n}, \mathbf{s})$. Most vimentin-positive peritubular cells could be found in the lamina propria of efferent ducts (o; black arrows), whereas in the other parts of the tubular system (d, i, t), vimentinnegative cells (red arrows) prevailed over positive cells (black arrows). Note that epithelial cells lining the rete channels can contain desmin (h, arrowheads) and/or vimentin (i, arrowheads). Control slides, where normal serum was used instead of primary antibodies, showed no positive brown immunostaining (e, $\mathbf{k}, \mathbf{p}$, u). Visualisation of the immunoreaction horseradish peroxidase/diaminobenzidine, counterstaining Mayer's haematoxylin. Black arrows - positive immunoreaction, red arrows - negative immunoreaction, arrowheads - positive immunostaining in epithelial cells of rete channels, asterisks - tubules. Scale bar: $50 \mu \mathrm{m}$. 

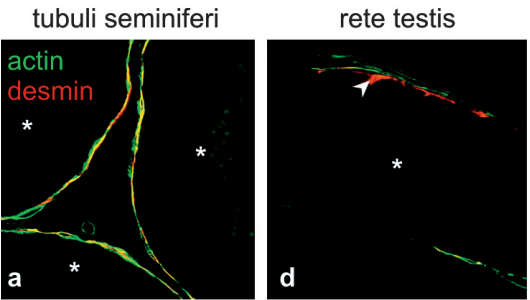

ductuli efferentes

ductus epididymidis
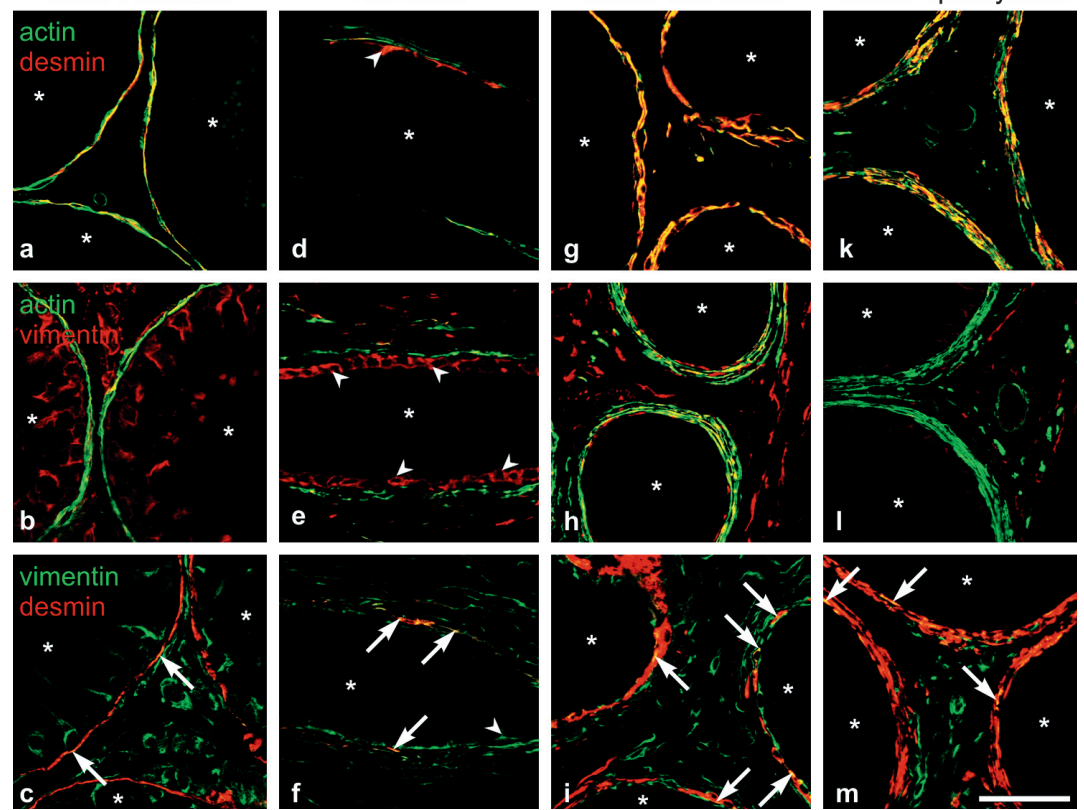

Fig. 2. Immunohistochemical detection of intermediate filaments of peritubular contractile cells in the canine testis and epididymis; tubuli seminiferi (a-c), rete testis channels (d-f), ductuli efferentes (g-i), and ductus epididymidis (k-m). In all parts of the tubular system, contractile cells detected by positive actin staining (a-b, d-e, g-h, k-l; green fluorescence) can contain either the muscle-type intermediate filament desmin (a, d, g, k; red fluorescence, overlay yellow) or vimentin (b, e, h, l; red fluorescence, overlay yellow). Desmin and vimentin double positive cells $(\mathbf{c}, \mathbf{f}, \mathbf{i}, \mathbf{m}$; yellow overlay of green vimentin and red desmin fluorescence, arrows) are rare; most of them can be found in the lamina propria of rete testis channels and efferent ducts. Note that epithelial cells lining the rete channels can contain desmin and/or vimentin (arrowheads). Visualisation of the immunoreaction Alexa Fluor 488 goat anti-mouse (green fluorescence) or Alexa Fluor 568 goat anti-mouse antibodies (red fluorescence). Arrows - positive immunoreaction, arrowheads - positive immunostaining in epithelial cells of rete channels, asterisks - tubules. Scale bar: $50 \mu \mathrm{m}$. 

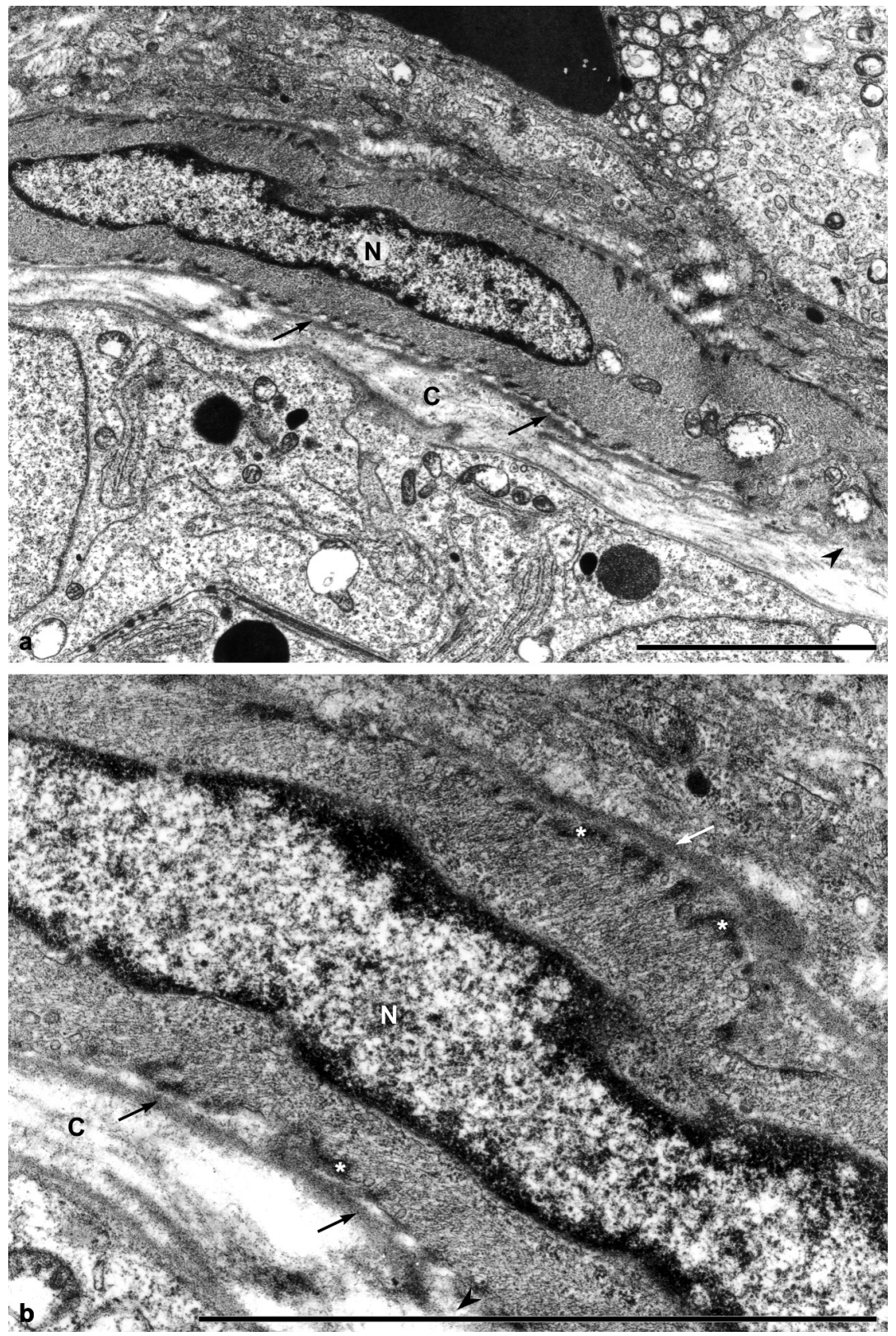

Fig. 3. Structure of contractile cells surrounding the seminiferous tubules in the canine testis, overview (a) and detail (b). Basal lamina (arrows) with gaps (arrowheads) and attachment plaques (asteriks) are characteristics of myofibroblasts; smooth surface of the nucleus $(\mathrm{N})$, spindle shape and uniform distribution of microfilaments of smooth muscle cells. C - collagen fibres. Transmission electron micrograph. Scale bar: $5 \mu \mathrm{m}$. 

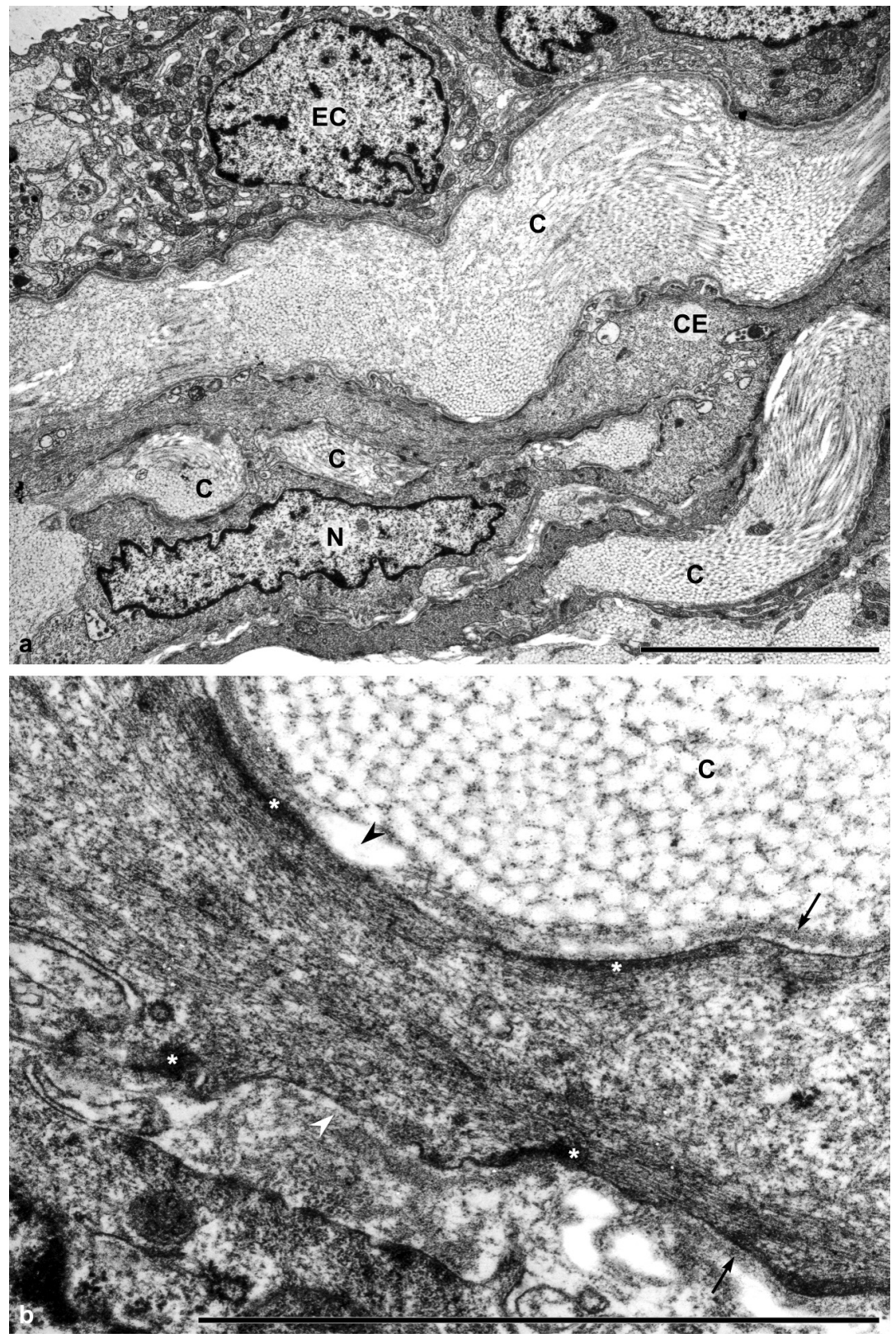

Fig. 4. Structure of contractile cells surrounding the rete channels in the canine testis, overview (a) and detail (b). Basal lamina (arrows) with gaps (arrowheads), attachment plaques (asteriks), lobated nucleus (N) and presence of cytoplasmic extensions (CE) characterise myofibroblasts. C - collagen fibres, EC epithelial cells. Transmission electron micrograph. Scale bar: $5 \mu \mathrm{m}$. 


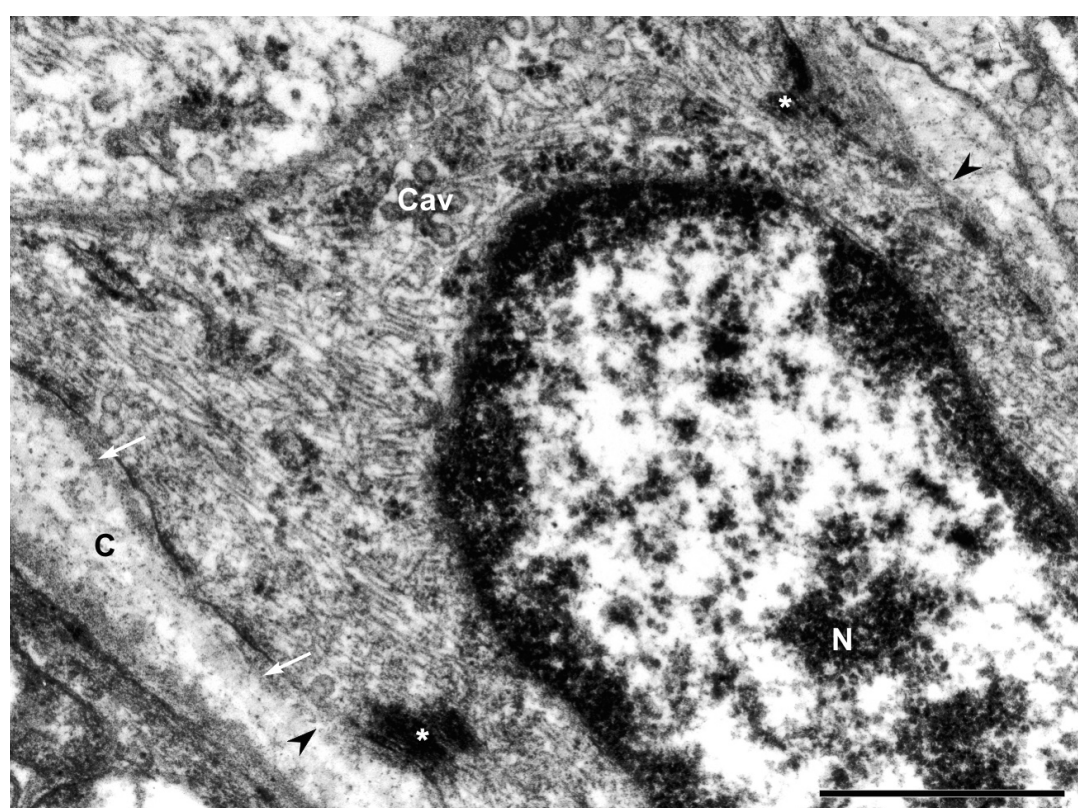

Fig. 5. Structure of contractile cells surrounding the efferent ducts in the canine testis. Basal lamina (arrows) with gaps (arrowheads), and attachment plaques (asteriks) are characteristics of myofibroblasts; smooth surface of the nucleus $(\mathrm{N})$, oblong cell shape and presence of caveolae (Cav) of smooth muscle cells. C - collagen fibres. Transmission electron micrograph. Scale bar: $1 \mu \mathrm{m}$. 

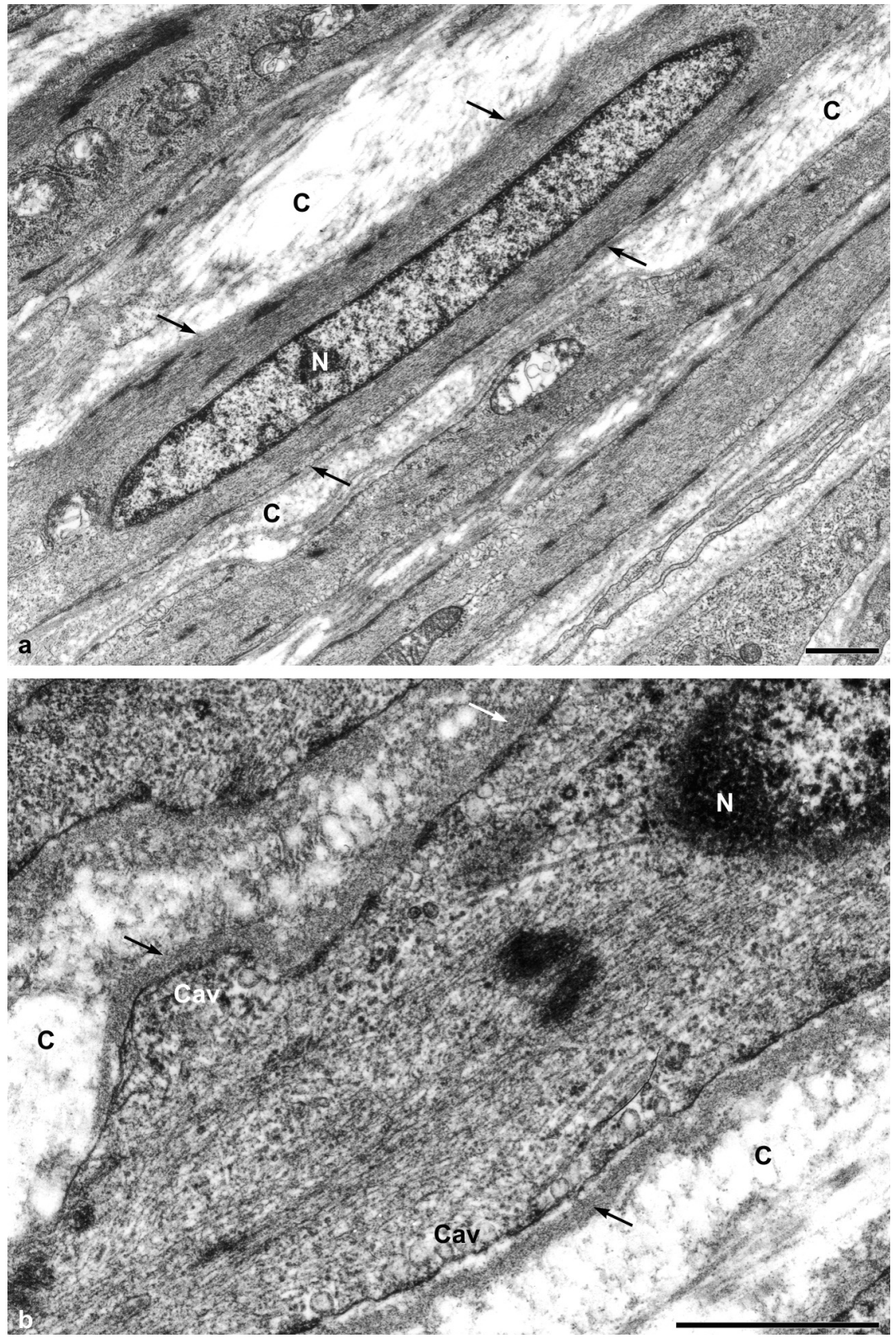

Fig. 6. Structure of contractile cells surrounding the ductus epididymidis of the dog, overview (a) and detail (b). Oblong cell shape, uniformly distributed microfilaments, smooth surface of the nucleus $(\mathrm{N})$, complete basal lamina (arrows) without gaps and presence of caveolae (Cav) characterise smooth muscle cells. C collagen fibres. Transmission electron micrograph. Scale bar: $1 \mu \mathrm{m}$. 

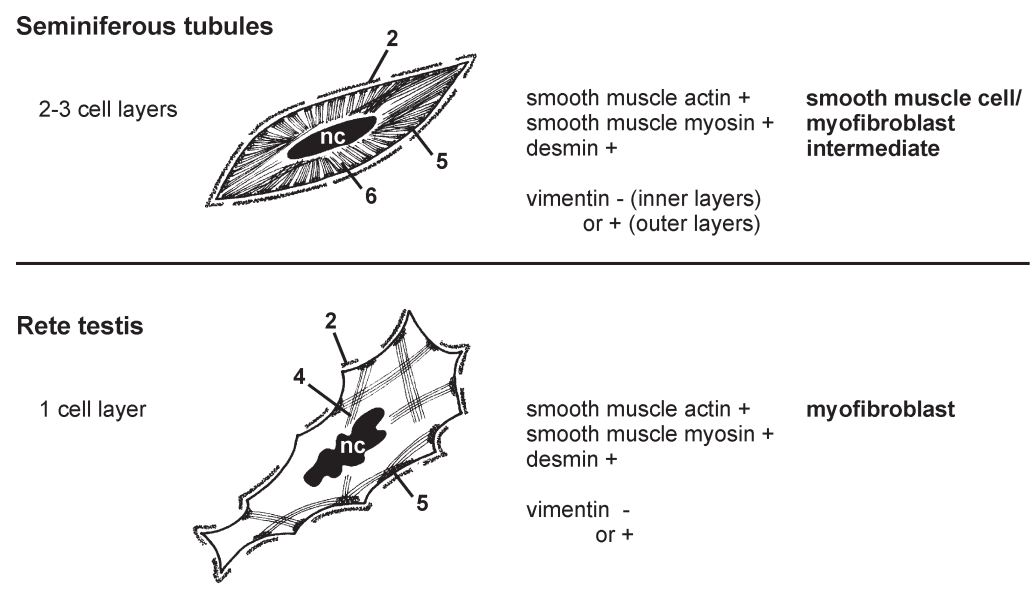

\section{Ductuli efferentes}

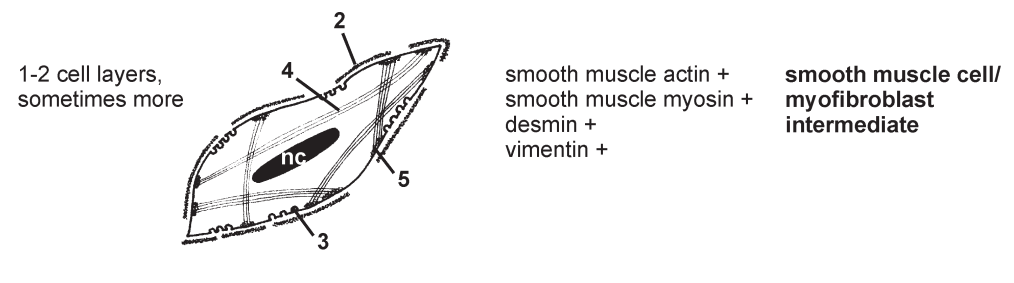

\section{Ductus epididymidis}

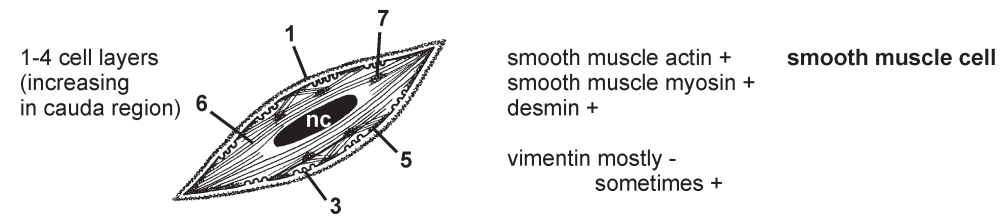

Fig. 7. Contractile cells surrounding the tubular system of the canine testis - structure, immunoreactivity and classification. 1 - complete basal lamina, 2 - incomplete basal lamina, 3 - caveolae, 4 - bundles of microfilaments (stress fibres), 5 - attachment plaque, 6 - uniformly distributed microfilaments, 7 - dense body, nc - nucleus. 